\title{
Root Phenology as a Factor of Competition
}

\section{Among Grass Seedlings}

\section{GRANT A. HARRIS}

Highlight: Roots of plants express phenology significant to competitive relationships, as do aerial parts. The following developmental stages of root phenology are proposed: (1) germination, (2) initial root growth, (3) rapid extension of root-soil contact, (4) dormancy, and (5) death. Examples of root phenological development in seedlings of three grass species are given to demonstrate effects on competition.

Range plants universally compete with each other for the limited resources (light, water, nutrients, soil, air) of their ecosystem. Lacking human or biological interference, competition is a major factor in the determination of composition in a given plant community. Plants have many adaptations (morphological, anatomical, physiological, and phenological) suiting them to a place in the ecosystem. Among these is a characteristic phenology or response to seasonal change. Timing of the developmental stages of aerial plant parts (vegetative, reproductive, and dormant) has significant survival value in competition situations; timing of phenological development in roots, though less obvious, similarly has important survival value. A recent literature search failed to disclose any reference to studies of root phenology, or to the development of theories of the function of variations in root phenology in plant competition.

The author has conducted a line of research over the years, aimed at discovering the controlling factors in competition between seedlings of important native and introduced perennial and annual grasses of intermountain west rangelands. This work has led to investigations of rooting habits, including phenology, which have significance in understanding plant competition. Published results of selec.ed experiments are recounted here in the development of conclusions regarding root phenology as a principle of plant competition.

Stands of perennial grasses have a natural competitive advant $4 \mathrm{se}$ over annual grasses. It is not necessary for them to begin .un seed following each aormant period. However, once mature plants are removed, and reestablishment from seed required, perennials are at a disadvantage. Seedlings of annuals

\footnotetext{
Author is chairman and professor, Department of Forestry and Range Management, Washington State University, Pullman 99163.

The study is Washington State University Agricultural Research Center Scientific Paper No. 4130, Project 0139. Cooperative research was supported in part by Bureau of Land Management, U.S. Department of the Interior, and Research Branch, Forest Service, U.S Dep. Agr

Grateful acknowledgement is made to coworkers and research assistants who have contributed materially to results reported herein. Dr. A. M. Wilson, Dr. J. R. Nelson, Dr. G. S. Campbell, and Dr. C. J. Goebel, as well as research assistants F. P. DeWitt, T. A Brannon, and C. E. McKinney have all been involved in the investigations supporting this paper.

Manuscript received August 23, 1976.
}

readily invade and become established on disturbed sites. Favorable root phenology is one of the adaptive strategies allowing this superior competitive ability. (Perhaps the same principles apply to annual and perennial forbs.) The following discussion relates primarily to competition between seedlings of annual and perennial grasses.

\section{Experimental Evidence}

Plant species used were from the semiarid rangelands of southeast Washington but occur over much of the western United States having similar environments. Field soils are generally of medium texture, $\mathrm{pH}$ 7 to 7.5 (nonsaline, nonalkaline), shallow, rocky, and often on steep topography. Precipitation is of the winter pattern, averaging 25 to $45 \mathrm{~cm}$ per year. Temperatures vary from a maximum of about $35^{\circ} \mathrm{C}$ in the warmest months (occasionally $40^{\circ} \mathrm{C}$ ) to a minimum of about $-5^{\circ} \mathrm{C}$ in the coldest months (occasionally to $-30^{\circ} \mathrm{C}$ ). Relative humidities average about $15 \%$ during the hot months. The ecosystem studied included bluebunch wheatgrass/little bluegrass and big sagebrush/ bluebunch wheatgrass communities (Agropyron spicatum/Poa sandbergii Vasey and the Artemisia tridentata Nutt./Agropyron spicatum habitat types).

Bluebunch wheatgrass [Agropyron spicatum (Pursh) Scrib. and Smith], a native perennial grass commonly of caespitose habit, historically dominated much of the rangeland area. Farming and ranching activities of European settlers in the late 19th and early 20th centuries modified vast areas of the native vegetation.

Cheatgrass (Bromus tectorum L.), a winter annual grass introduced to the western United States from Europe in the late 19th century, largely replaced bluebunch wheatgrass in noncultivated areas wherever it had been destroyed. Once established, cheatgrass effectively delayed the reestablishment of bluebunch wheatgrass.

Medusahead [Taeniatherum asperum (Simonkai) Nevski], a winter annual grass introduced from the Mediterranean region in the late 19th century, did not spread rapidly until the 1950 's, but is now displacing cheatgrass on the more mesic sites. It is less desirable as a range plant than cheatgrass, itself a plant of low forage value except for a short period in spring.

Crested wheatgrass [Agropyron desertorum (Fisch.) Schult] is a perennial cool-season grass introduced from Russia and widely used in rangeland seeding. It is drought resistant, withstands grazing use well, and is productive, nutritious, and palatable, especially for spring grazing use.

A laboratory experiment tested germination responses of bluebunch wheatgrass, cheatgrass, and medusahead seeds to a range of temperatures and water potentials (Table 1). Although medusahead germination was delayed by low temperature and low water potential, it occurred more rapidly than in the other species. In general, germination increased with increases in temperature and in water potential. Cheatgrass germination was much slower than medusahead but 
Table 1. Influence of temperature ( $\leq \mathrm{C}$ and water potential (bars) on early germination (\%) of bluebunch wheatgrass, cheatgrass, and medusahead seeds.

\begin{tabular}{|c|c|c|c|c|c|c|c|}
\hline \multirow[b]{3}{*}{$\begin{array}{c}\text { Water } \\
\text { potential }\end{array}$} & \multirow[b]{3}{*}{ Temperature } & \multicolumn{6}{|c|}{ Germination } \\
\hline & & \multicolumn{3}{|c|}{4 days } & \multicolumn{3}{|c|}{6 days } \\
\hline & & $\begin{array}{l}\text { Bluebunch } \\
\text { wheatgrass }\end{array}$ & Cheatgrass & Medusahead & $\begin{array}{l}\text { Bluebunch } \\
\text { wheatgrass }\end{array}$ & Cheatgrass & Medusahead \\
\hline \multirow[t]{3}{*}{0} & 10 & 0 & 1 & 39 & 2 & 23 & 73 \\
\hline & 20 & 33 & 36 & 78 & 66 & 51 & 87 \\
\hline & 30 & 31 & 26 & 85 & 50 & 33 & 87 \\
\hline \multirow[t]{3}{*}{-6.2} & 10 & 0 & 0 & 3 & 0 & 12 & 52 \\
\hline & 20 & 14 & 20 & 81 & 44 & 37 & 88 \\
\hline & 30 & 16 & 11 & 73 & 30 & 14 & 77 \\
\hline \multirow[t]{3}{*}{-11.4} & 10 & 0 & 0 & 0 & 0 & 0 & 22 \\
\hline & 20 & 1 & 4 & 41 & 14 & 11 & 60 \\
\hline & 30 & 0 & 3 & 45 & 2 & 6 & 49 \\
\hline
\end{tabular}

slightly faster than bluebunch wheatgrass. Cheatgrass germination decreased at the highest temperature. These data indicate the advantage medusahead has over the other species in early fall establishment.

Rates of primary root elongation of bluebunch wheatgrass, cheatgrass, and medusahead were compared in a field study by Harris (1967). It is characteristic of bluebunch wheatgrass primary roots to branch near the surface, while cheatgrass and medusahead primary roots grow rapidly to 18 to $20 \mathrm{~cm}$ before branching.

Primary root growth rates differed considerably between the annuals and bluebunch wheatgrass (Fig. 1). Bluebunch wheatgrass roots grew slowly from October 11 until mid-November, when growth practically ceased. Soil temperature at the average depth of bluebunch wheatgrass root tips was $0^{\circ} \mathrm{C}$ on December 13 and remained near freezing until late March, during which time the average maximum root length increased only about $5 \mathrm{~cm}$.

Cheatgrass and medusahead seedling roots began post-germination growth at a more rapid rate than bluebunch wheatgrass and continued thus all winter. At growing root tip depths, soil temperatures were 2 to $3^{\circ} \mathrm{C}$ higher for cheatgrass and up to $4^{\circ} \mathrm{C}$ higher for medusahead than for bluebunch wheatgrass. Medusahead roots grew slightly faster than cheatgrass roots. Primary root growth of cheatgrass had practically stopped by late March, with little additional growth in April and early May. Many medusahead roots had reached the lower ends of the growth medium by February 9.

Primary roots of cheatgrass and medusahead grew mostly during winter when leaves showed little growth. However, primary roots of bluebunch wheatgrass grew most rapidly during the summer months, when adventitious root and stem growth was occurring in that species.

Dense stands of the annual grasses exhausted available soil water at shallow depths where bluebunch wheatgrass roots were growing when soils warmed up after winter (Harris 1967). This was demonstrated in the laboratory by growing bluebunch wheatgrass and cheatgrass

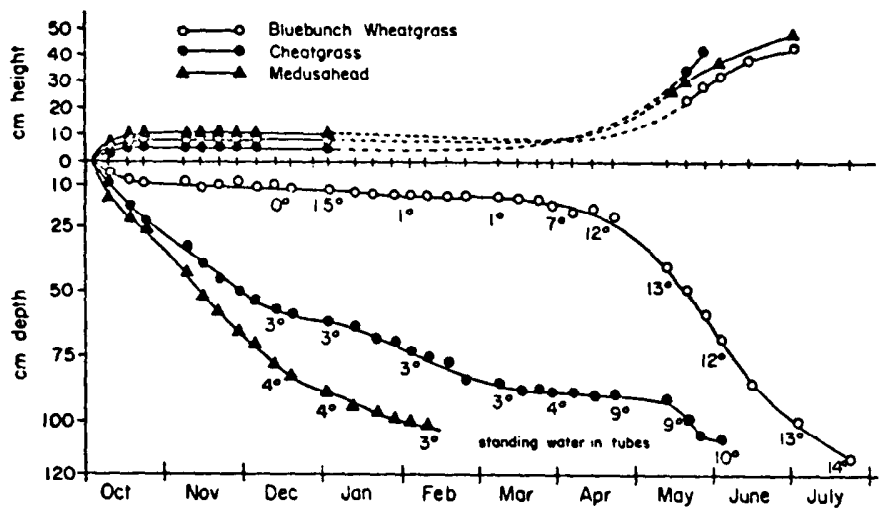

Fig. 1. Seasonal leaf and root growth of bluebunch wheatgrass, cheatgrass, and medusahead in glass tubes in the field (1963-64). Leaf heights represent tallest leaf; root depths represent longest visible primary root tip. Used by permission of the Ecological Society of America; from Harris, 1967, medusahead added.) seedlings in boxes. Seedlings were arranged on a $1-\mathrm{cm}$ grid so that each of 49 bluebunch wheatgrass seedlings was surrounded by several of the 244 cheatgrass seedlings.

Cheatgrass roots grew deeper than the bluebunch wheatgrass roots and reduced soil water to potentials less than -15 bars in the upper soil levels where bluebunch wheatgrass roots were growing (Fig. 2). Cheatgrass root tips were growing at depths where soil water potential was less than -1 bar, and readily available.

A similar experiment included medusahead and crested wheatgrass (Harris and Wilson 1970). The earlier results were confirmed, and in addition it was shown that (a) medusahead behaved similarly to cheatgrass in reducing surface layer soil water, and (b) the growth rate of primary roots of crested wheatgrass was similar to that of the annual grasses at $2^{\circ} \mathrm{C}$ and would probably be a successful competitor if seeded in the fall (Fig. 3).

Excavations of roots and determination of soil water in the field confirmed that bluebunch wheatgrass seedlings failed to live through the first summer because of soil water depletion by winter-growing cheat-

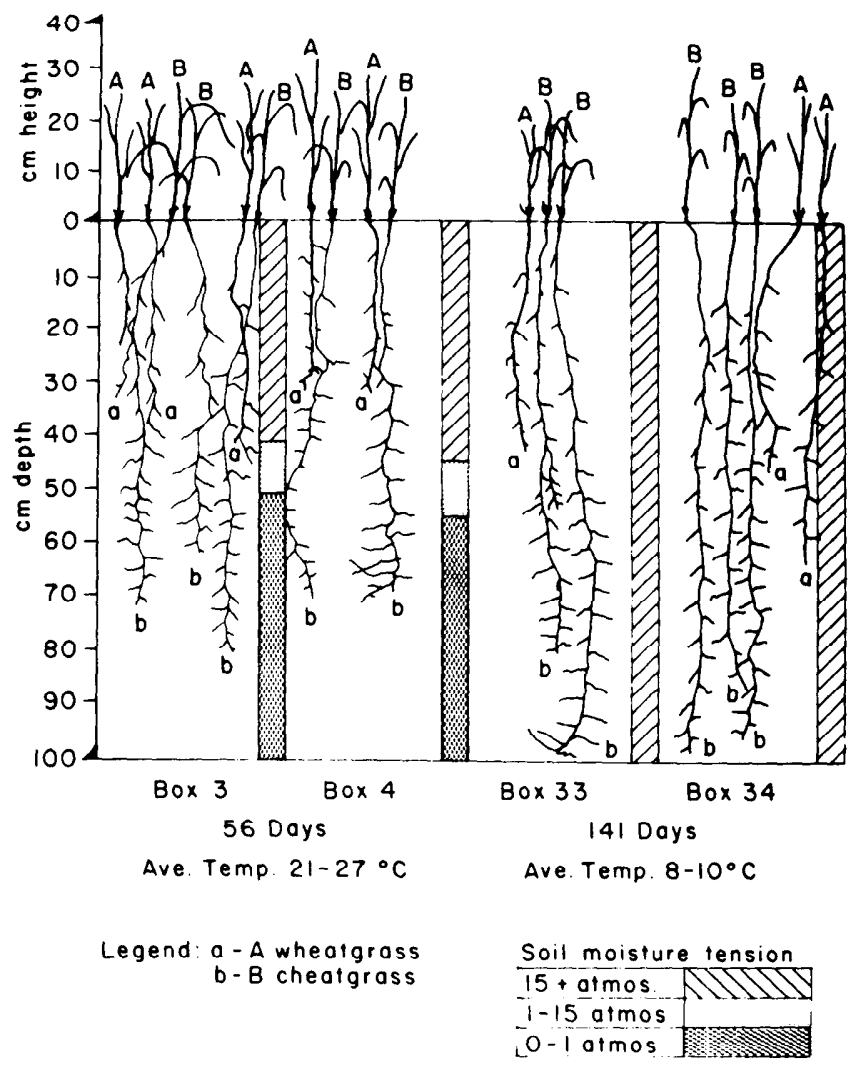

Fig. 2. Development of bluebunch wheatgrass and cheatgrass seedlings in relation to available soil water. Two replications of each run at room temperature and winter temperature in high density cheatgrass. (Used by permission of the Ecological Society of America; from Harris, 1967.) 


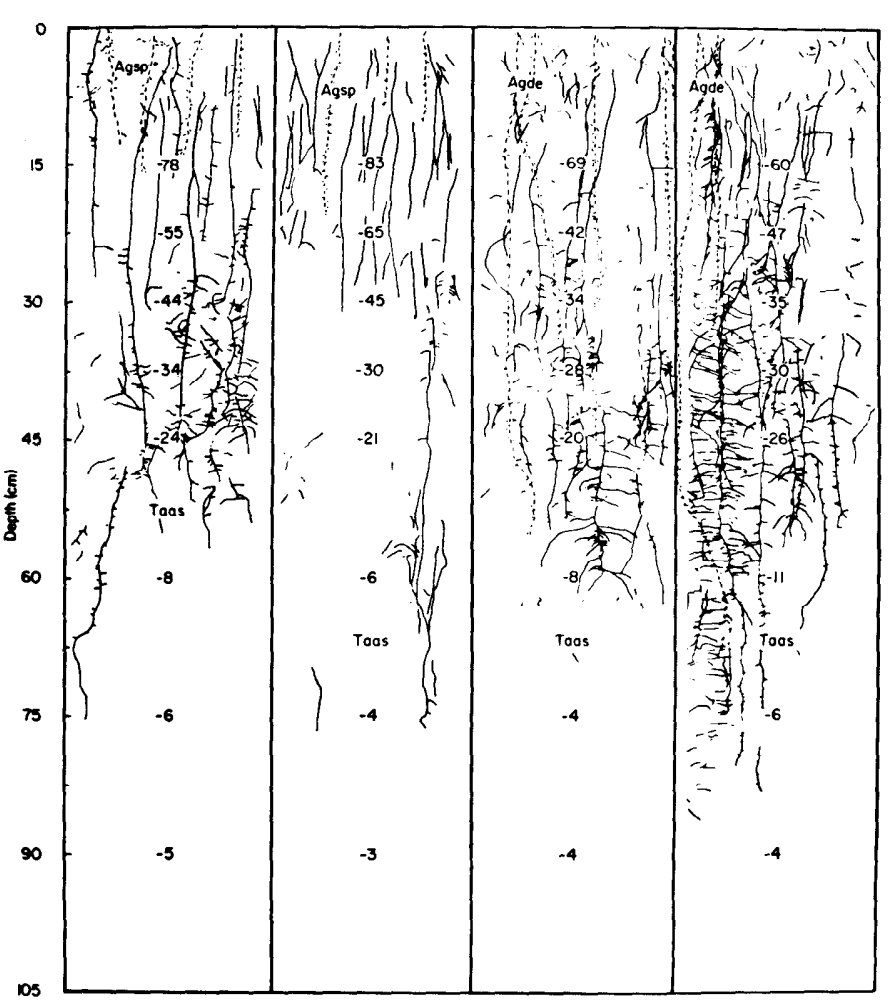

Fig. 3. Root growth at low temperature of bluebunch wheatgrass and crested wheatgrass (broken lines) growing in competition with cheatgrass (solid lines). Only exposed roots of cheatgrass were traced. Roots of perennial grasses growing near the side of the box were excavated and then traced in approximately their original positions. Soil water potentials (in bars) are indicated at appropriate depths. (Used by permission of Ecological Society of America; from Harris and Wilson, 1970.)

grass seedlings (Harris 1967). The winter response of bluebunch wheatgrass seedling primary roots is to practically cease growth while those of cheatgrass and medusahead continue.

Bluebunch wheatgrass is known to vary greatly throughout its range in western North America. Response of primary roots of ecotypes from 52 sites, Arizona to Alaska, to temperatures near freezing was examined by DeWitt (1969). Primary roots of a collection from Morgan, Utah, (source 15) grew 10 times as fast at $2^{\circ} \mathrm{C}$ as a collection from Moscow, Ida. (source 30). Nevertheless, the fastest growing bluebunch wheatgrass roots grew at only about one-fifth the rate of cheatgrass in these tests.

In the "glass tube" experiment of Harris (1967), the initiation and growth of adventitious roots was also recorded. Since the plants were growing singly in separate tubes, competition was avoided. Data representative of selected dates throughout the growing season showing phenological response to the environment are presented in Table 2 .

Adventitious root development was first recorded in cheatgrass on October 18, in medusahead on November 8, and in bluebunch wheatgrass on November 29. Bluebunch wheatgrass response was not only late, but the rate of growth was slow compared with that of the annuals. By January 1 adventitious roots of cheatgrass and of medusahead were more than five and six times as deep as those of bluebunch wheatgrass, respectively. This difference increased further before the soil began to warm in the spring. With the higher spring temperatures, bluebunch wheatgrass root growth increased and by July 1 the average number of adventitious roots was comparable with the number produced by the annuals.

Microscopic examination of seedling root cross sections reveals that bluebunch wheatgrass roots are twice the diameter of, and their cell walls many times thicker than those of cheatgrass (Harris 1967). In size and thickening of cell walls, medusahead primary roots are intermediate. Cheatgrass probably goes into dormancy early because its root system is poorly protected against droughty soils (Fig. 4). The endodermal layer is thin and the root poorly adapted to translocate water through the dry, hot upper soil layer in summer conditions.

\section{Root Phenology and Competition}

Among plants, competition occurs when growth and reproduction of one is hampered by the presence of another, or, when the resources of a site required by one plant are reduced by another. Except in early stages of invasion on bare areas, competition is practically always present in natural stands. The variability in root phenology outlined in the preceding experiments is reflected in the ability of those plant species to compete with each other for site resources.

For purposes of this discussion, it is proposed that the steps through which these roots developed be classified into five characteristic stages, namely (1) germination, (2) initial growth, (3) rapid extension, (4) dormancy, and (5) death. Seasonal variables directly controlling root phenology include available soil water, temperature, and nutrient level. In addition, roots are indirectly affected by light intensity, day length, fire, and other factors which directly affect phenology above ground.

Germination generally occurs most dependably slightly below the soil surface and is the beginning of acive life history in annuals, being crucial to population maintenance. On the other hand, perennials may reproduce by tillering (as in bluebunch wheatgrass and crested wheatgrass) or by rhizomes. But where there are no established mature plants, germination is required in these species also.

Table 2. Leaf and stem development in three grass species (planted Oct. 4) during fall, winter, and spring, growing in glass tubes.

\begin{tabular}{|c|c|c|c|c|c|c|}
\hline Species & Oct. 25 & Nov. 15 & Dec. 13 & Jan. 3 & May 19 & July 1 \\
\hline \multicolumn{7}{|l|}{ Bluebunch wheatgrass } \\
\hline Length of primary root (mm) & 93.0 & 112.0 & 108.0 & 118.0 & 504.0 & $1,071.0$ \\
\hline Number of stems & 1.0 & 1.0 & 1 & 1.2 & 3.2 & 9.0 \\
\hline Number of roots & 0.6 & 0.8 & 1.3 & 1.4 & 6.6 & 23.4 \\
\hline Length of adventitious roots (mm) & 0.0 & 0.0 & 55.0 & 80.0 & 1 & 1 \\
\hline \multicolumn{7}{|l|}{ Cheatgrass } \\
\hline Length of primary root (mm) & 242.0 & 403.0 & 582.0 & 648.0 & $1,050.0$ & 2 \\
\hline Number of stems & 1.1 & 2.4 & 1 & 3.1 & 6.6 & 1 \\
\hline Number of roots & 1.1 & 3.2 & 3.8 & 3.9 & 15.6 & 20.3 \\
\hline Length of adventitious roots (mm) & 22.0 & 70.0 & 392.0 & 420.0 & 1 & 1 \\
\hline \multicolumn{7}{|l|}{ Medusahead } \\
\hline Length of primary root (mm) & 288.0 & 516.0 & 788.0 & 879.0 & 2 & 2 \\
\hline Number of stems & 1.0 & 3.2 & 1 & 3.7 & 11.3 & 1 \\
\hline Number of roots & 1.0 & 3.5 & 3.7 & 3.7 & 15.7 & 27.0 \\
\hline Length of adventitious roots (mm) & 0.0 & 210.0 & 450.0 & 523.0 & 1 & 1 \\
\hline
\end{tabular}

'Measurement not available for various reasons.

"Root length exceeded depth of growth medium $(1,100 \mathrm{~mm})$. 

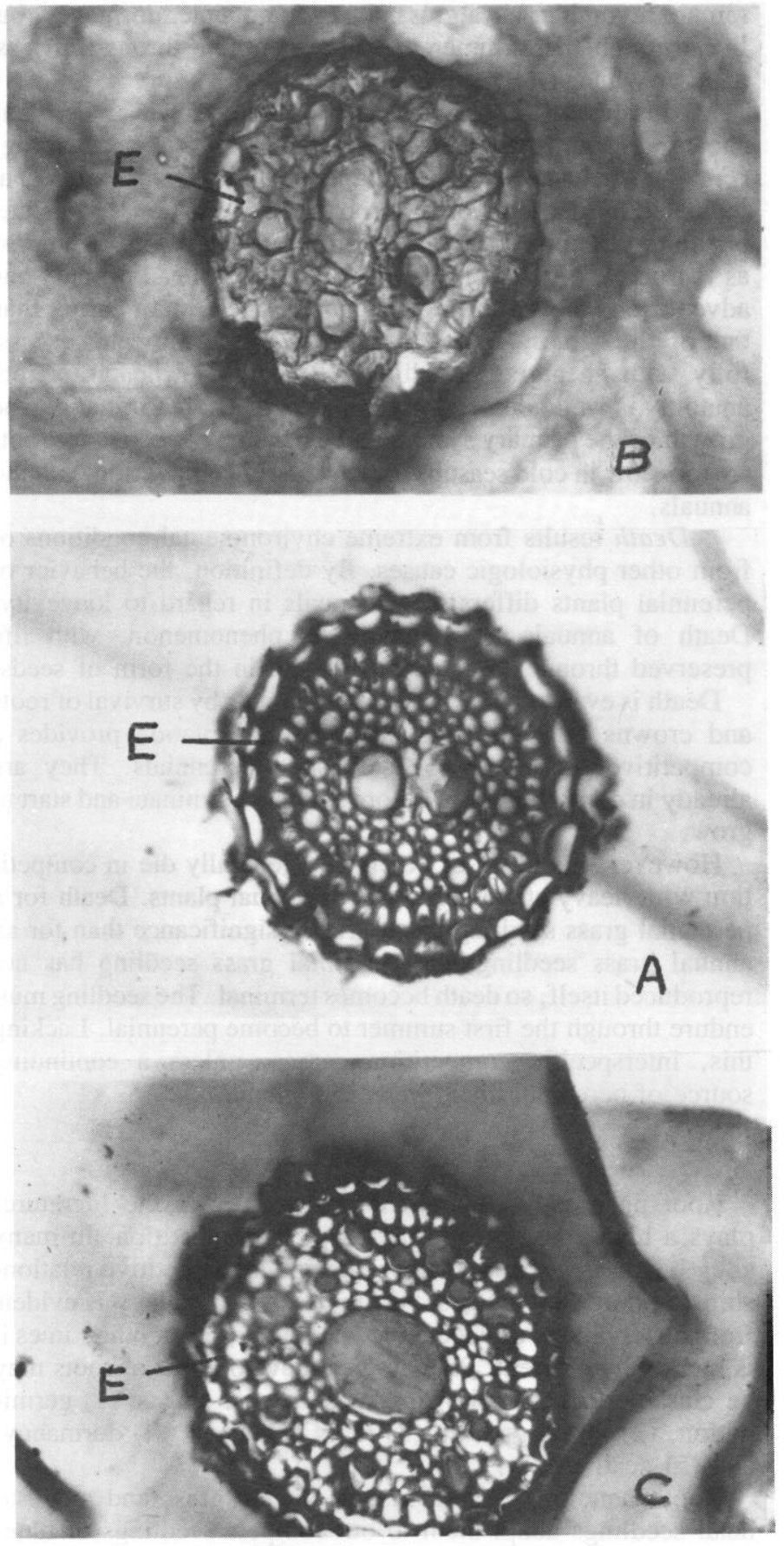

Fig. 4. Photomicrographic comparison of endodermis $(E)$ development in root sections of bluebunch wheatgrass $(A)$, cheatgrass $(B)$, and medusahead $(C)$ (not to scale).

Rate and amount of germination are important in competition on disturbed areas because early establishment in large numbers often confers site dominanance. The species studied normally germinate in the fall in this region, although germination is sometimes delayed by unusual weather until spring (or winter). Early fall rains are usually light in amount, and frequently repeated during a storm period. Soil water potential changes quickly over a short time. Thus the ability to germinate rapidly at relatively low water potentials $(-5$ to $-10 \mathrm{bar})$ and variable temperatures is advantageous.

Medusahead germinates significantly faster and more completely than either cheatgrass or bluebunch wheatgrass under these conditions (Table 1). Evidence of germination in medusahead may be observed as early as 8 to 10 hours after moistening and shows surprising energy at low temperatures $\left(10^{\circ} \mathrm{C}\right)$ and droughty conditions $(-11.4$ bars water tension). Even in the best situations, the differences in germination shown for these two annuals is highly important for their survival, with the advantage going to medusahead. Cheatgrass has a smaller but measurable advantage over bluebunch wheatgrass in this regard.

Seed dormancy is a mechanism to reduce the chances of germination at a time when subsequent survival is unlikely. This mechanism is present in all three species. Nelson and Wilson (1969) have demonstrated that seed dormancy in medusahead is relative to inhibitory substances in the awns of fresh seed. Three-year-old seed germinated well. Cheatgrass seed germinates poorly at high temperatures, and, like medusahead, contains biological inhibitors which must "decay" before rapid germination can proceed. In both of these annuals, inhibitory effects have disappeared by early fall. In bluebunch wheatgrass, germination is so slow that it does not usually occur until a dependable source of water is available.

Overall, speed and energy of germination strongly favors medusahead in competition with cheatgrass, and both annuals in competition with bluebunch wheatgrass. Large numbers of vigorous, rapidly germinating seedlings place a heavy stress on available resources, thus reducing the opportunity for survival, especially for late germinating, slow growing species such as bluebunch wheatgrass.

Initial growth describes an elongation process of the hypocotyl in newly germinated seedlings, or a breaking of summer dormancy in established perennial plants. Rates of primary root growth in grass species are determined genetically (Pavlychenko 1942). Rapid elongation of the primary root is critical at the beginning of the fall growth period when water potentials fluctuate widely at the soil surface. This growth, combined with initiation of adventitious roots, prepares the plant to exert dominance on the site. After fall rains begin, dependable soil water is generally available at a depth of 3 to $10 \mathrm{~cm}$, but the surface can dry rapidly. Seedlings of species developing adventitious root primordia, or seminal roots (Esau 1953, p. 473), and would more quickly produce adventitious roots.

Low fall and winter soil temperatures following germination greatly handicapped initial bluebunch wheatgrass root development. Normally slow root growth, (even at optimal fall temperatures) practically ceased in bluebunch wheatgrass at soil temperatures approaching freezing. Roots of the annual grasses continued to grow throughout winter even at low temperatures (see Fig. 1).

Rapid extension of roots occurs in a period of favorable growth, and includes both the primary and adventitious systems in seedlings (perennial and annual), as well as reactivation of root tip growth in established perennial plants. Competitive advantage is gained by exploiting a greater volume of soil and capturing the resources contained therein, to the disadvantage of competing plants. The full potential for production of adventitious roots can only be demonstrated where ecosystem resources are in excess of plant requirements. Established perennials respond similarly to phenological stimuli by extending overwintering dormant roots to provide new thin-walled root surfaces and root hairs for efficient soil-plant interchange.

Rapid root extension began during late fall and early winter in the annual grasses, but was delayed by low temperatures until late spring and early summer in bluebunch wheatgrass. Figure 1 shows growth rates in primary root systems under field tempera- 
tures, without competition, confirming the above statement. In the same experiment, it was demonstrated that in the annuals, length and numbers of adventitious roots also increased during the winter at a much faster rate than in bluebunch wheatgrass (Table 2).

Cheatgrass and medusahead roots, growing faster and in greater numbers than bluebunch wheatgrass, effectively removed available soil water at depths where bluebunch wheatgrass roots were growing. Soil moisture content at depths where bluebunch wheatgrass roots were growing was raised to tensions in excess of -15 bars in laboratory growth boxes held at 21 to $27^{\circ} \mathrm{C}$ (boxes 3 and 4 , grown 58 days, Fig. 2). At the same time, cheatgrass roots had access to adequate deep water supplies at tensions less than -1 bar. At $8^{\circ}$ to $10^{\circ} \mathrm{C}$, plants grown in competition demonstrated even greater differences between cheatgrass and bluebunch wheatgrass root growth rates (boxes 13 and 34, Fig. 2). Here cheatgrass exhausted available soil water to the bottom of the boxes. It is interesting to note that both species were still surviving at these low temperatures and resultant low transpiration rates.

Figure 3 shows that crested wheatgrass seedling roots were able to grow and compete with cheatgrass roots at $2^{\circ} \mathrm{C}$, while bluebunch wheatgrass seedling roots lacked this ability (Harris and Wilson 1970). This difference in root phenology between bluebunch and crested wheatgrasses undoubtedly explains the greater success obtained in crested wheatgrass seedings where cheatgrass is present.

Dormancy is a physiologic reaction of plants to normal seasonal extremes, not severe enough to cause death but too difficult for active growth. Annual plants normally are adapted through phenologic responses to avoid seasonal extremes. Cheatgrass and medusahead germinate in the fall, develop extensive root systems during the winter, and quickly reproduce during spring, the season most conducive to growth. They pass their dormant period in the seed stage.

Leaves and upper stems of established bluebunch wheatgrass seedlings die in early August, while stem bases and roots become dormant. Prior to this, leaf and stem primordia have developed in buds on the lower stem nodes. Few first-year seedlings of bluebunch wheatgrass produce seed under natural conditions; and because of unfavorable competition with the annuals in earlier phenological stages, bluebunch wheatgrass seedlings frequently die without the opportunity of summer dormancy.

All the species studied are winter hardy and only occasionally die as a result of low temperatures. As discussed above, medusahead and cheatgrass roots increase quite actively during winter, but bluebunch wheatgrass roots and stems are dormant. This winter-dormant reaction in bluebunch wheatgrass seedlings is an important cause of failure to compete by establishment in stands of the annual grasses.

Summer dormancy and death are responses to decreasing water availability and increasing temperature stress. Cheatgrass enters summer dormancy (seed stage) about 2 weeks earlier than medusahead and 5 to 7 weeks earlier than bluebunch wheatgrass. This response appears to be related to differences in anatomical structure of roots of the three species (Fig. 4). On days with high temperatures, leaf water potentials drop rapidly, and apparently cheatgrass roots cannot move water fast enough (from deep soil layers where it is available) to keep the leaves from becoming dessicated. Cheatgrass roots have a relatively poorly developed endodermis layer to insulate against hot, dry surface soils. On the other hand, if summer soil water conditions remain favorable, cheatgrass plants do not enter dormancy, but live through the summer and may continue through at least another winter (Harris 1967).

Medusahead not only germinates and grows earlier than cheatgrass, but its root anatomy adapts it for a later phenology (Fig. 4). Medusahead is also adapted to higher temperatures, as indicated by germination and root growth reactions. This later phenology is not a disadvantage in competition with cheatgrass as is true for bluebunch wheatgrass. Medusahead primary and adventitious root phenology is comparable with or earlier than that of cheatgrass, so medusahead seedlings compete successfully with cheatgrass seedlings. Bluebunch wheatgrass root anatomy is well adapted for summer growth, but initiation and growth of the primary system and extension of secondary roots are too slow in cold seasons for successful competition with the annuals.

Death results from extreme environmental conditions or from other physiologic causes. By definition, the behavior of perennial plants differs from annuals in regard to longevity. Death of annuals is a phenologic phenomenon, with life preserved through the stressful season in the form of seeds.

Death is evaded in herbaceous perennials by survival of roots and crowns in a dormant state. This adaptation provides a competitive advantage to established perennials. They are already in control of a site before annuals germinate and start to grow.

However, seedlings of perennials generally die in competition with heavy stands of vigorous annual plants. Death for a perennial grass seedling has a greater significance than for an annual grass seedling: the perennial grass seedling has not reproduced itself, so death becomes terminal. The seedling must endure through the first summer to become perennial. Lacking this, interspecific competition ceases, unless a continuing source of perennial plant seeds is available.

\section{Conclusions}

Root phenology, though not recognized in the literature, plays a highly significant part in plant competition. In many situations it is not possible to understand competitive relationships without root studies. At times, root phenology is evident from observations of vegetative phenology, but at other times it is markedly different. Phenological development of roots may be classified in the following recognizable stages: (1) germination, (2) initial growth, (3) rapid extension, (4) dormancy, and (5) death.

Root phenology characteristics of cheatgrass and medusahead seedlings adapt them to out-compete seedlings of bluebunch wheatgrass. Seeds of annual grasses germinate earlier in the fall, under drier and colder conditions than do bluebunch wheatgrass seeds. Once germinated, roots of the annuals grow faster, not only under conditions of favorable fall temperature and moisture, but at near-freezing soil temperatures typical of winter in this region. The annuals also are adapted to increase number and length of roots during winter so that by spring they are in control of the site. The annual grasses exhaust upper profile available moisture supplies to depths beyond the reach of developing bluebunch wheatgrass roots. Consequently, bluebunch wheatgrass seedlings succumb to drought, under these conditions, before producing seeds. The annuals also die, but not before reproduction. If a bluebunch wheatgrass seedling does survive the summer, its root phenology pattern changes to include a period of summer dormancy, which provides a competitive advantage over annuals. Successful establishment 
of bluebunch wheatgrass requires control of annuals through recognition of weaknesses revealed by study of their phenologic responses.

\section{Literature Cited}

DeWitt, F. P. 1969. Early development response to low temperature in Agropyron spicatum collected from native stands in western North America. MS Thesis, Washington State Univ., Pullman. p. 49.
Esau, K. 1953. Plant Anatomy. Wiley, New York.

Harris, G. A. 1967. Some competitive relationships between Agropyron spicatum and Bromus tectorum. Ecol. Monogr. 37:89-111.

Harris, G. A., and A. M. Wilson. 1970. Competition for moisture among seedlings of annual and perennial grasses as influenced by root elongation at low temperature. Ecology 41:530-534.

Nelson, J. R., and A. M. Wilson. 1969. Influence of age and awn removal on dormancy of medusahead seeds. J. Range Manage. 22:289-290.

Pavlychenko, T. K. 1942. Root systems of certain forage crops in relation to management of agricultural soils. Can. Nat. Res. Comm. Pub. 1088. p. 46. 